\title{
Educational Game "Mr. Foodi" Healthy and Nutritious Food for Children
}

\author{
Fadila Tiara* \\ Software Engineering Technology, \\ Agricultural Polytechnic of \\ Samarinda, Samarinda, Indonesia \\ dilahhh484@gmail.com \\ *Corresponding author
}

\author{
Reza Andrea \\ Software Engineering Technology, \\ Agricultural Polytechnic of \\ Samarinda, Samarinda, Indonesia \\ reza@bibirdesign.com
}

\author{
Suswanto \\ Software Engineering Technology, \\ Agricultural Polytechnic of \\ Samarinda, Samarinda, Indonesia \\ suswanto.attala@gmail.com
}

Received: 2020-02-05; Revised: 2021-02-20; Accepted: 2021-03-05; Published: 2021-03-14

\begin{abstract}
Children really like food that makes them interested in trying it, but the food that makes them interested is likely to be one of them. Source of problems for his health. Food and drinks that do not know the manufacturing process have an impact on children's development. Therefore, an educational game was created to get to know healthy and nutritious food. This is so that children can know which food is good for them and which food is not good for consumption. In its implementation, game development can use Construct2. Construct2 is a device that is used specifically for making games for platforms 2D. Games that use construct 2 can be applied to educational games about healthy and nutritious food using the method finite state machine. FSM is a game smart agent development in the field of artificial intelligence. Methods Finite state machine (FSM) is a control system design methodology that describes the behavior or the working principle of the system by using the three things, namely, state, event and action.
\end{abstract}

Keywords- Educational Games, Kids, Construct2, Finite State Machine, Healthy and Nutritious Food

\section{INTRODUCTION}

Children really like foods that make them interested in trying them, however the food that they are attracted to is likely to be a source of problems for their health. Due to the processing that does not meet the nutritional adequacy rate and the presence of mixtures such as artificial sweeteners, flavorings, preservatives and other causes can be a high risk to health if consumed continuously. This results in these foods not meeting the predetermined nutritional standards, where this needs to be avoided by consuming less of these foods.

If the food given to children does not contain good nutrition, it can interfere with the child's digestion and interfere with the child's growth process (Siti \& Novita, 2017). Food and drinks that do not know the manufacturing process have an impact on children's development. For example, fried foods cause diarrhea, artificial sugars cause diarrhea and cramps / upset stomach, fibrous foods because bloating and gas, spicy foods cause indigestion and heartburn. Even food mixed with hazardous substances that are not known to the manufacturing process, can cause children to be poisoned and at risk of death. Therefore, created game educational to get to know healthy and nutritious food. This is so that children can know which food is good for them and which food is not good for consumption.

\section{LITERATURE REVIEW}

\section{A. Study of literature}

According to a study conducted by (Saputro et al, 2018) from the Satya Wacana Christian University entitled "Development of Learning Media Using Construct 2 Applications in Class VII Algebra Material". The research objective was to develop a game platform based educational game learning media for seventh grade students of SMP. The benefits of this learning media are that the game platform-based educational game application helps students learn algebra, the display design and games are attractive to students so that they are not boring, and the material contained helps students understand algebraic concepts and solutions. The research method used was the research design borg and gall consisting of ten steps. The data collection technique consisted of observation, questionnaires and tests.

According to research conducted by (Kurniawaty, 2017) entitled "Increasing Knowledge about Healthy Food through Cooking Class Activities". The purpose of this study was to analyze and explain the implementation of cooking class activities to increase knowledge about healthy food. The benefit of this research is to increase knowledge about healthy food in grade 3 SDN Kebonsari I, Cimahi City. The research method used was the research developed by Kemmis \& Taggart. The actions taken in this study consisted of two cycles; each cycle consists of two meetings. Each cycle consists of planning, action, observation, reflection.

According to research conducted by (Adiwijaya \& Christyono, 2015) entitled "Designing an Android-Based Mathematics Learning Platform Educational Game Using construct 2". The purpose of this learning media is to make educational and interesting games so as to increase interest in learning and make it easier to learn mathematics. The benefit of this learning media is that it is good for learning comprehension at this time or before, more emphasis is placed on visual education that looks attractive with 
additional images and sounds. The research method used is the prototype method because this model is a classical model that is systematic in nature. In order to facilitate this design, the things that need to be considered are the concepts consisting of content, text, and graphics. Then design using the method unified modeling language (UML)which functions to describe the limitations and functions of the system in general, made using use case diagrams, activity diagrams, sequence diagrams, class diagrams and actors (Jubilee, 2012).

According to research conducted by (Yustin et. al, 2016) from the University of Tanjungpura entitled "Designing a Mathematics Learning Educational Game Application Using Construct 2". The purpose of this learning media is to be able to make alternative media that can be used by children in learning basic mathematics which is fun and can improve children's abilities in learning basic mathematics. From this, the researcher made a learning alternative in the form of an educational game in which there was material on the operation of basic mathematical numbers.

According to research conducted by (Widodo, 2017) from Universitas Nusantara PGRI Kediri entitled "Designing an Android-Based Mathematics Education Game for Classes 4-6 Using Construct 2" the purpose of this research is to increase knowledge about mathematics and also hone the speed of thinking for SD students Class 4 - 6 TPQ BAITUL ABIDIN Jln. Melati, Suwaluh, Sambirejo, Pare - Kediri using the "Mathematics" educational game media. The method used is Rapid Application Development (RAD) or rapid prototyping. $\mathrm{RAD}$ is a software development process model that is classified as an incremental (multilevel) technique.

Table 1. Comparison of Research Journals

\begin{tabular}{|l|l|l|}
\hline Authors & Year & Title \\
\hline $\begin{array}{l}\text { Titon Agung } \\
\text { Saputro, Et. al }\end{array}$ & 2018 & $\begin{array}{l}\text { Learning Media } \\
\text { Development Using } \\
\text { Construct2 Applications in } \\
\text { Class VIIAlgebra Material }\end{array}$ \\
\hline Lia kurniawaty & 2017 & $\begin{array}{l}\text { Increased Knowledge } \\
\text { About Healthy Food } \\
\text { Through Cooking } \\
\text { ClassActivities }\end{array}$ \\
\hline $\begin{array}{l}\text { Mohamad } \\
\text { Adiwijaya, Et. al }\end{array}$ & 2015 & $\begin{array}{l}\text { Designing Educational Games } \\
\text { for Android-Based } \\
\text { Mathematics Learning } \\
\text { Platforms Using Construct2 } \\
\text { Designing }\end{array}$ \\
\hline $\begin{array}{c}\text { Jada Ario Yustin, } \\
\text { Et. al }\end{array}$ & 2016 & $\begin{array}{l}\text { Mathematics Learning } \\
\text { Educational Game Applications } \\
\text { Using Construct2 }\end{array}$ \\
\hline $\begin{array}{l}\text { Danang Wahyu } \\
\text { Widodo, Et. al }\end{array}$ & 2017 & $\begin{array}{l}\text { Mathematics Education Game } \\
\text { for Class 4-6 SD } \\
\text { UsingConstruct2 }\end{array}$ \\
\hline
\end{tabular}

\section{B. Multimedia}

Multimedia, in terms of language, consists of 2 words, namely multi and media. Multi means many or more than one. While media is the plural form of medium, it is also defined as a suggestion, container, or tool. The term multimedia itself can be interpreted as data transmission and manipulation of all forms of information, whether in the form of words, images, videos, music, numbers, or handwriting where in the computer world, this form of information is processed from and in the form of digital data (Darma, et al. 2009)

\section{Game}

Game comes from the English meaning game. In each game, there are different rules for starting the game, making the types of games more varied. Because one of the functions of games is as a stress reliever or a feeling of boredom, almost everyone likes to play games, whether small children, teenagers or adults, maybe only different from the types of games they play. (Ridoi, 2010).

\section{Educational Games}

Games that have educational content are better known as educational games, this educational type game aims to provoke children's interest in learning subject matter while playing games, so that with happy feelings it is hoped that students can more easily understand the subject matter presented. This type actually refers more to the content and purpose of the game, not the actual type. Games are an effective tool for teaching because they contain learning principles and instructional techniques that are effective in strengthening difficult levels. (Yustin et. al, 2016)

\section{E. Construct 2}

Construct 2 is an HTML 5 based game maker tool specifically for platforms 2Ddeveloped by Scirra. Construct 2 does not use a special programming language, because all the commands used in the game are arranged in Evensheet which consists of Events and Actions. (Ridoi, 2010)

\section{F. HTML5}

HTML is (Hypertext Markup Language). The meaning of each word that makes up the HTML abbreviation is: (Jubilee Enterprise, 2014)

1. Hypertext is text which when clicked will take you from one document to another. In practice, hypertext is in the form of a link that can take you to the world of the internet which is very broad.

2. Markup is a tag (a kind of code) that regulates the layout and visual appearance that we see on a website, including fonts, text colors, images, and so on.

3. Language which is a sign that HTML is a kind of script programming.

\section{G. Finite State Machine}

Finite state machine or better known as FSM is a model that has been used for years for the development of intelligent game agents in the section artificial intelligence. A finite state machine states is a device or model that has a limited number of at a certain time and can operate on the input either by transitioning from one state to another causing an output or action to decide 
something. Finite state machines can only be used for one condition at each event (Asmiatun \& Putri, 2017).

Development of formal language can be viewed as an abstract entity, namely a set of symbol alphabet strings certain. However, language can also be viewed as entities abstract that can be recognized or generated through a computation engine. Machines that can recognize the language of this class are finite state machines.

There are several definitions of finite state machines (FSM) or often referred to as finite state automata (FSA).

1. FSM is defined as a computation device that has an input information of a thestring and an output which is one of two values that can be accepted and rejected.

2. Finite automata is a mathematical model of a system with inputs and outputs concrete. The system can reside in one of a finite number of internal configurations called state.

3. FSM is a control system design methodology that describes the behavior or working principle of the system by using the following three things: state, event and action. The system can switch or transition to state another if it gets input or events certain, either from external devices or components in the system itself. (Asmiatun and Putri, 2017)

\section{H. Healthy and Nutritious}

Food Healthy food is food that is free from harmful ingredients and contains nutrients that are beneficial to our bodies. The dangerous ingredients in question include msi dyes, preservatives and artificial sweeteners. Meanwhile, nutrients that are beneficial to the body, such as those containing protein, carbohydrates, fats, vitamins, water, and minerals.

Nutritious food is food that meets the nutritional needs of our bodies. God created man with such a perfect order that he also needed complete nutrients as a constituent (protein, carbohydrate, fat, vitamins, water and minerals). Nutritious food is unnecessary and not always expensive, but it must be healthy and nutritious which also contains various substances that are beneficial to our bodies.

\section{RESEARCH METHODS}

\section{A. Time and Place of}

This research was conducted in 002 Public Elementary School, Bukuan / Palaran Samarinda Seberang area. The research time will be carried out in the odd semester of 2019 - 2020 and will be carried out for a period of approximately 6 (six) months, starting from October 2019 - March 2020. This includes activities such as preparation, research, writing thesis proposals, data collection, and application development and preparation of reports.

\section{B. Research Tools and Materials}

System requirements in this study use the following tools and materials.

1. Hardware specifications used in making this game educational are as follows.

1) Laptop Acer Aspire 3

2) Processor AMD A4 - 9120E

3) Memory (RAM) 4GB DDR4
4) HDD $500 \mathrm{~GB}$
5) Monitor 14 inch
6) VGA: AMD Radeon R3 Graphics
7) Stationery
8) Printer

2. The Specifications software used in making this game educational are as follows.

1) Operating System Windows 10

2) Adobe Corel Draw X7

3) Application Construct2

4) GiveYourFontsMono

5) Website.2.APK.Builder v4

6) access Internet

3. Materials used are as follows.

1) Object visuals in PNG and GIF format.

2) Music and Sound

3) Short material about the knowledge of healthy and nutritious food.

\section{Research Procedures The}

Multimedia development methodology Picture 1 consists of six stages, namely concept (drafting), design (designing), material collecting (material collection), assembly (making), testing (testing), and distribution (distribution). These stages can be performed sequentially and can be performed sequentially. Even so, the concept stage is the very first stage to work on (Dharwiyanti \& Wahono, 2003).

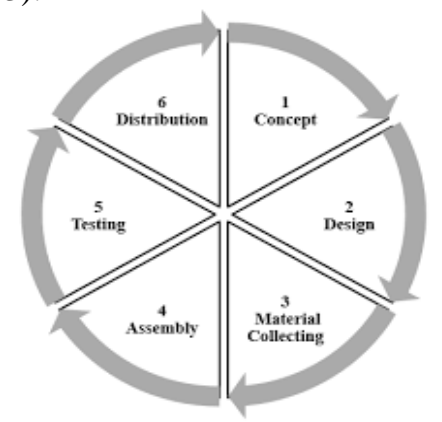

Picture 1. Multimedia Development

1. Concept

Stage The concept stage (conceptualization) is the stage for determining the objectives and who is the user of the program (audience identification). The goals and end users of the program affect the multimedia nuance as a reflection of the identity of the organization that wants information to reach the end user.

2. Design

Design (designing) is the stage of making specifications regarding architecture program style, appearance, and requirements material material/such as making characters game and game backgrounds.

3. Material collecting

Material collecting is the stage of collecting materials according to the needs that are done. These materials include textbooks, images clip art, photos, animation, video, audio, etc. which can be obtained 
free of charge or by ordering from other parties according to the design. This stage can be done in parallel with the stage assembly.

\section{Assembly}

Stage assembly is the stage of making all objects or multimedia materials. Making applications is based on the stage design, such as storyboards, flowcharts, and the structure or flow of a program.

5. Testing

Phase Testing (testing) is performed after completing the stage of manufacture(assembly)by running an application or program and seeing if there is a mistake or not. The first stage in this phase is called the alpha testing stage(alpha test), the testing done by the manufacturer or the manufacturer's own environment. After passing testing alpha, beta testing involving end use will be carried out. When testing beta, the method used is the method User Acceptance Testing (UAT).

6. Distribution

At this stage, the application will be stored in a storage medium. If there is not enough storage media to accommodate the application, compensation for the application will be made. This stage can also be called the evaluation stage for developing finished products to make them better. The results of this evaluation can be used as input for the stage concept of the next product.

\section{The design concept}

\section{Use Case}

In the picture below about the use case diagram Picture 2 is a process flow introduction of healthy and nutritious food through games educational.

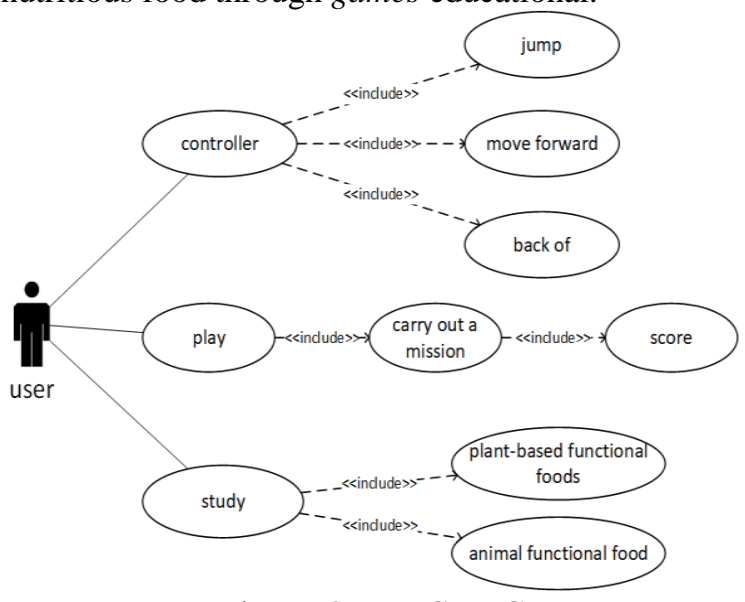

Picture 2. Use Case Game

\section{Diagram Activity}

Activity Diagram flow depicting various activities within the system that is being designed, from the beginning of flow, decision that happens, and how it ends. Below are some diagrams of the activity of each flow which is directly related (Rusli et. al, 2017).

\section{1) Controller The}

the first thing Picture 3 that the user does is control the object, which consists of jumping, forward, and backward, then the system will start moving the object's character.

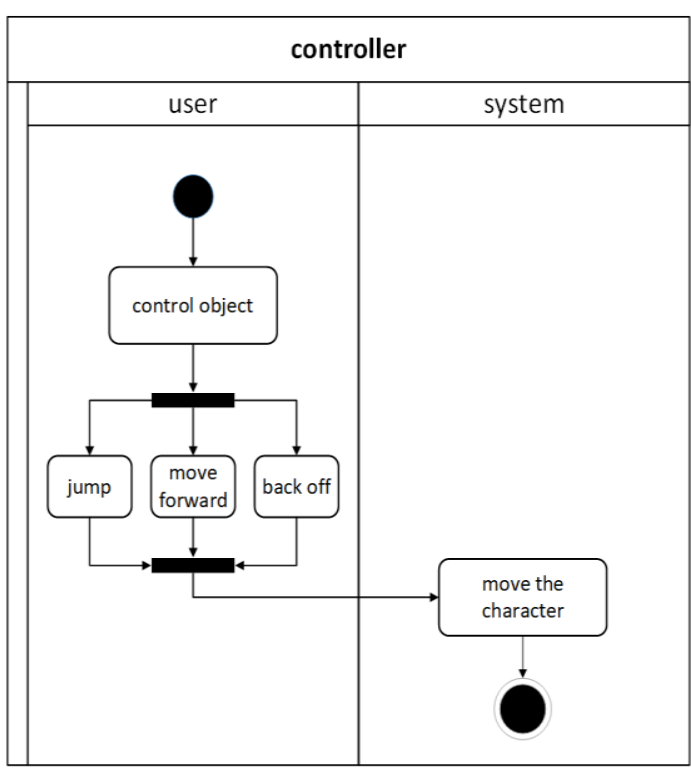

Picture 3. Game Controller Activity

\section{2) Activity Diagram The}

The first thing Picture 4 the user does is to open the level view, then the user / player will choose the level, after the game is over, the system will display the score that the user/ player can get.

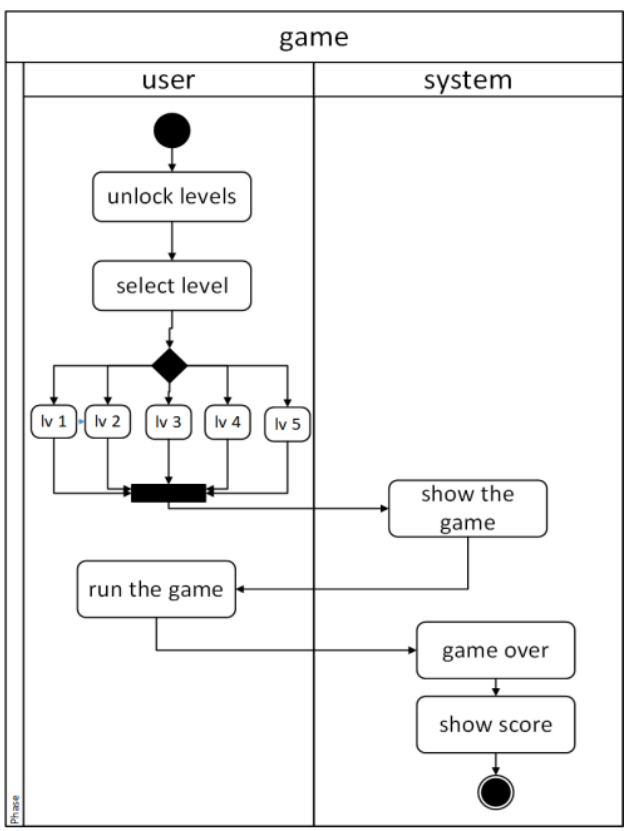

Picture 4. Game Activity

\section{3) Sequence Diagram The}

The sequence diagram Picture 5 in the game that will be created illustrates the behavior of objects in the use case by describing the lifetime of objects and messages to be sent and received between objects. 


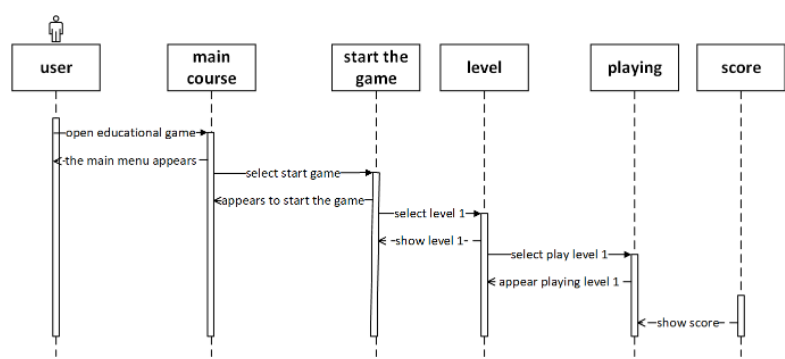

Picture 5. Sequence diagram of play menu level 1

\section{RESULTS AND DISCUSSION}

The following are the results of the application to Game Educational Know Healthy and Nutritious Food based on Android. This display is made in such a way as to support everything needed by this software to run properly.

\section{A. Display of the splash screen}

page on the page splash screen in Picture 6 there is an animation of moving characters and loading.

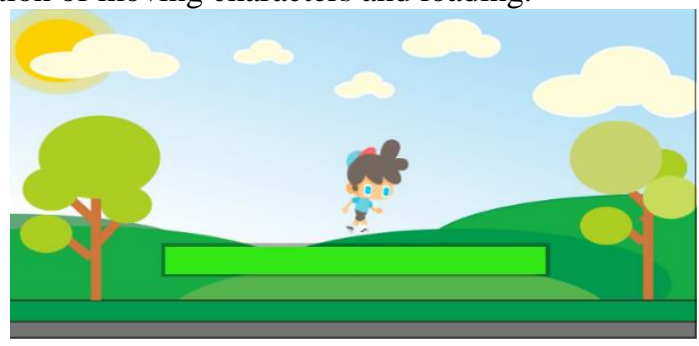

Picture 6. Display of the splash screen

\section{B. Story Game Page Views}

On the page game story in Picture 7 is a page that displays the story of the game characters and the missions the player will play.

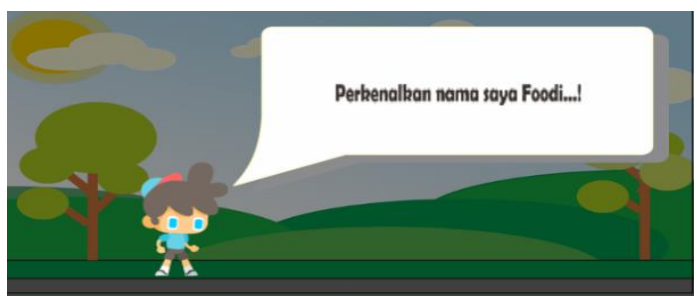

Picture 7. Story Game Page Views

\section{Display Main Menu page}

is no main menu page in Picture 8 which contains the name of the game and there are a few buttons, the PlayButton, Button Encyclopedia, Button, Main Hint ButtonMusic, SoundButton, Button info.

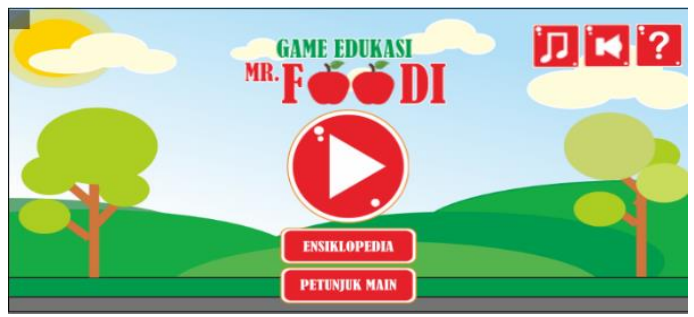

Picture 8. Display Main Menu page

\section{Pageviews Encyclopedia}

On page encyclopedia on the image object 9 which contains a summary of healthy and nutritious food objects in the game, and there is a button, Back music button, sound button.

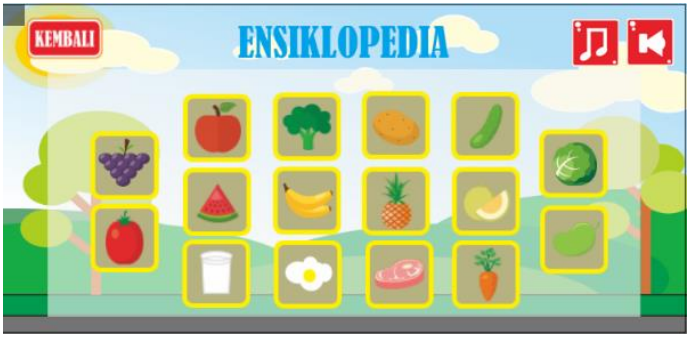

Picture 9. Pageviews Encyclopedia

\section{E. Display Play Guide Page}

On the play manual page in Picture 10 which contains a brief explanation of the game and instructions for playing the game. The button back functions to return to the main menu page, the buttons right and left function to change each slide in the image.

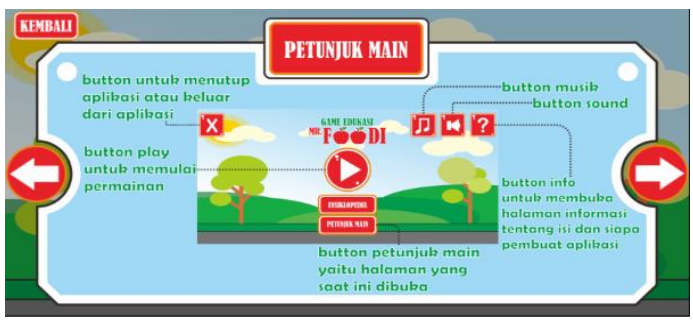

Picture 10. Display Play Guide Page

\section{F. See page Level}

Page level in the image 11 is a page that serves to provide Opera- levels of the game, where level this made up of five levels, If the level can be completed then it will go to level, its next automatically opens level is locked.

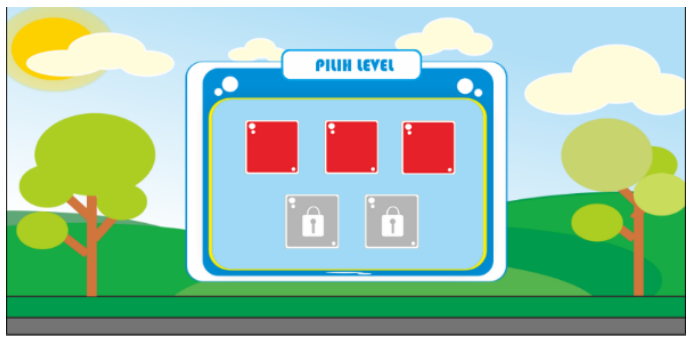

Picture 11. See page Level

\section{G. Pageviews Games}

page level 1 on the image 12 Players must complete the obstacle by pointing characters using button control game to get past the enemy to get to the flag, players must complete level 1 first so they can continue to level 2. Each level has a difficulty level - starting from the level lowest or easy to high level or difficult. At level 1 or easy the obstacles that are traversed are like easy steps to get through, as well as the levels next, until at level 5 or difficult the 
stepping is getting more difficult and the enemy is getting more and more.

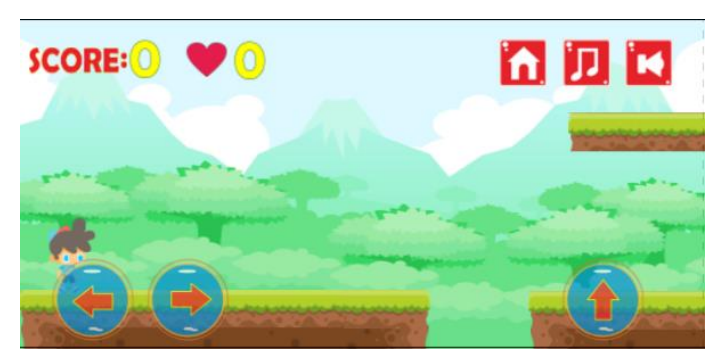

Picture 12. Pageviews Games

\section{CONCLUSIONS}

This educational game application to recognize healthy and nutritious food is made using the Construct2 game engine which helps the teacher learning system in grade $\mathrm{V}$ elementary schools through educational games that can be implemented to students and provide a new atmosphere of learning via Smartphone.

From the test results of respondents for SD Negeri 002 Palaran, Samarinda Seberang, it can be concluded that the results of the UAT application get an overall value of $87 \%$, thus the application tested is feasible to use.

Game development "Mr. Foodi" uses 6 stages of multimedia development, namely, concept, design, material collection, assembly, testing and distribution. Application of the method finite state machine to players to determine the response of behavior players to changing conditions that occur in players and in the game environment. In this game the player /user can control the player and pass the obstacles in each level.

This application can only run on one platform, namely Android. This weakness is a reference so that it can be developed again so that it can be used on several platforms such as PC and iOS.

The addition of these food objects can help teachers in learning methods for elementary school students using media smartphones.

\section{REFERENCES}

Adiwijaya, M., S, KI, \& Christyono, Y. 2015. Designing an Game for an Educational Platform Based Mathematics Learning Android- Using Construct 2.Journal Transient, 128-133.

Asmiatun, S., \& Putri, AN 2017. Learn to Make Games 2D and 3DUsing Unity. Sleman: CV Budi Utama.

Darma, S, J., \& A, S. 2009. Smart Multimedia Book. Jakarta: Mediakita.

Dharwiyanti, S., \& Wahono, RS 2003. Introduction to the Unified Modeling Language (UML). 01-13.

Jubilee, Enterprise. 2014. HTML 5 Manual Book. Jakarta: PT Elex Media Kompu tindo.

Jubilee, Enterprise. 2012. Smart HTML5 + CSS3 + DreamWeaver CS6. Jakarta: PT Elex Media Komputindo.

Kurniawaty, L. 2017. "Increasing Knowledge About Healthy Food Through PlayingActivities
Cooking Class". Journal of Children Advisory Research and Education, 01-17.

Ridoi, M. 2010. Easy Ways to Make Educational Games with Construct 2: Simple tutorials. Maskha.

Rusli, M., Hermawan, D., \& Supuwiningsih, NN 2017. Innovative Learning Multimedia: Basic Principles and Development Models. Yogyakarta: Andi.

Saputro, TA, Kriswandani, \& Ratu, N. 2018. "Development of Learning Media UsingApplications in Construct 2Class VII Algebra Material". Journal of Mathematical Theory and Applications, 01-08.

Siti, A., \& Novita, PA, 2017. Belajar Creating Games 2D and 3DUsing Unity. Yogyakarta: CV Budi Utami.

Widodo, S. 2017. "Design of Educational Games Math Grades 4-6Sd Android-Based Using Construct 2 Game Design AndMath Education Class 4-6 SD Based On Android Using the Construct2".01-05.

Yustin, JA, Sujaini, H., \& Irwansyah, MA 2016. "DesigningApplications Game MathematicsUsing Construct 2". Journal of Information Systems and Technology, 01-05 